DOI

\title{
«КВАРТИРНЫЙ ВОПРОС» В СИСТЕМЕ ГУЛАГа В ГОДЫ ВЕЛИКОЙ ОТЕЧЕСТВЕННОЙ ВОЙНЫ
}

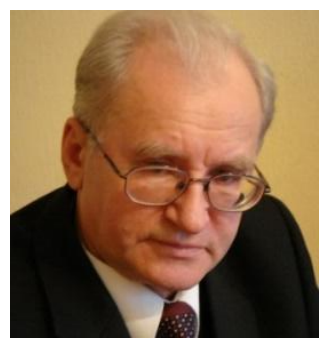

М.Г. Суслов, профессор, д-р ист. наук профессор кафедры военной педагогики и психологии Пермского военного института войск национальной гвардии Российской Федерации, Пермь suslovmi@yandex.ru

Аннотация. Показано положение дел с обеспеченностью жильем заключенных в системе ГУЛАГа в годы Великой Отечественной войны. Прослежена динамика изменений с жильем для заключенных на разных этапах войны, причины некачественного жилья и плохого обустройства жилых помещений, а также меры, принимаемые органами власти и руководства ГУЛАГа для решения жилищного вопроса в местах массового размещения лишенных свободы.

Ключевые слова: ГУЛАГ, жильё для заключенных в 1941-1945 гг.

\section{"APARTMENT QUESTION" IN THE GULAG SYSTEM IN YEARS GREAT PATRIOTIC WAR}

\author{
Mikhail Suslov, \\ doctor of Historical Sciences (Advanced Doktor) Professor, \\ PhD, professor Perm Military Institute of Internal Troops of Russia, \\ Associate Professor (Senior Lecturer of the Department of Pedagogy). Perm \\ suslovmi@yandex.ru
}

\begin{abstract}
The article examines the state of affairs with the provision of housing for prisoners in the GULAG system during the Great Patriotic War. It shows the dynamics of changes in housing for prisoners at different stages of the war, the reasons for poor - quality housing and poor arrangement of living quarters, as well as measures taken by the authorities and the leadership of the GULAG to resolve the housing issue in places of mass placement of prisoners.
\end{abstract}

Keywords: GULAG, housing for prisoners in 1941-1945. 
Квартирный вопрос важен в любое время для каждого в отдельности и для всех вместе. В условиях неудачного начала войны проблема обостряется до предела. Разрушение жилого фонда маленьких сел и больших городов вынуждало власти искать решения проблем размещения больших масс людей.

Положение усугублялось эвакуацией 10 млн человек из западных областей в восточные регионы страны, которых надо было обеспечить жильем. Те же проблемы возникали и в отношении людей, находящихся и работавших в местах заключения.

В разные годы количество лагерного населения было очень разным. Разной была и плотность лагерного населения по регионам страны. Если в 1930 г. в исправительно-трудовых лагерях находилось 179 тысяч человек, то в последующие годы в связи с коллективизацией и индустриализацией их численность заметно увеличивается. На 1 января 1941 г. в лагерях и колониях содержалось 1929729 человек, рассредоточенных по разным регионам страны [1, с. 399].

С началом Великой Отечественной войны ситуация существенно изменяется. Количество заключенных сокращается в 1942 г. до 1777 тысяч, в 1943 г. - до 1484 тысяч, в 1944 г. - до 1179 тысяч человек, но в связи с перемещением лагерей и лагерного населения из западных областей в восточные регионы страны количество и концентрация их на Урале, в Сибири, на Дальнем Востоке и Средней Азии заметно увеличивается.

Решение задач, возложенных на ГУЛАГ, обеспечивалось достаточно большим коллективом сотрудников, 9 \% которых приходилось на работников лагерного сектора, 41,6 \% составляли работники военизированной охраны и 49,3\% - работники производственного сектора лагерей и колоний [2, д. 77, л. 200-201].

В конце 1942 г. в системе ГУЛАГа было 200 тысяч человек (без охраны), из них рабочих и ИТР - 143 500, служащих - 56500. В числе вольнонаемных и служащих было около 50 тысяч бывших заключенных, отбывавших за особо опасные преступления и по освобождении закрепленных до конца войны за лагерями по вольному найму без права выезда с территории лагеря [2, д. 35, л. 418].

Последние в целях исключения постоянного общения с вольной обслугой размещались в специально отведенных для них общежитиях или отдельных бараках. Однако документы архивов 
содержат немало материалов, в которых жилищно-бытовые условия содержания личного состава отмечались как не везде удовлетворительные [3, д. 1, Л. 34-35].

На особом режиме находились каторжане. В соответствии с инструкцией НКВД от 11 июня 1943 г. «О порядке содержания осужденных к каторжным работам» каторжане должны были проживать в бараках, которые бы запирались на ночь и были отделены от остальной лагерной зоны высоким забором.

Картина бытовых условий для заключенных менялась в зависимости от периода войны и региона, в котором они размещались. При быстром продвижении немецких войск вглубь нашей территории многие лагеря были утрачены. Было эвакуировано 27 исправительно-трудовых лагерей и 210 колоний, где содержалось 750 тысяч заключенных.

Кроме того, за годы войны подверглись расформированию 69 исправительно-трудовых лагерей, одно Управление исправительно-трудовыми лагерями и колониями и 15 отделов исправительно-трудовых колоний. Это вынуждало власти уплотнять действующие лагеря и колонии и строить новые. За время войны было организовано 40 новых исправительно-трудовых лагерей, 11 УИТЛК и 15 ОИТК НКВД - УНКВД.

Строительством и обустройством жилых помещений занимались сами лагеря и колонии, а также контрагентские организации наркоматов 17 отраслей народного хозяйства, которые использовали труд заключенных.

В переписке Наркомата внутренних дел с другими наркоматами вырисовывает картина в целом и в частностях. 30 августа 1941 г. заместитель наркома внутренних дел Чернышов на запрос Наркомата авиапромышленности дать стройтрестам № 2, 12 и 14 дополнительную рабочую силу отвечает отказом, поскольку тресты не подготовлены к этому. «Так, в г. Молотове в лагерном пункте на жилой площади, рассчитанной на 3500 заключенных, уже размещено 8000 человек (трест 12)» [1, с. 88].

Второго октября 1941 г. в письме заместитель наркома Чернышов в Главвоенстрой при СНК СССР пишет, что Окружное военно-строительное управление на Урале «не создает даже минимальных условий для содержания заключенных. Строительство № 290 в Красноуфимске предоставило только 4 палатки вместимо- 
стью по 60 человек на контингент в 1500 человек. Заключенные размещены в окрестных деревнях небольшими группами, в совершенно неприспособленных помещениях» [1, с. 98].

28 февраля 1942 г. Чернышов пишет начальнику Бакалстроя в Челябинск: «Прибывшие заключенные размещены в землянках, не приспособленных к жилью, и находятся в антисанитарном состоянии. Среди заключенных поголовная вшивость. Уборные и выгребные ямы отсутствуют. Сушилки, бани и дезкамеры до настоящего времени не построены» [1, с. 99].

Седьмого марта 1942 г. в письме начальнику Главвоенстроя при СНК СССР отмечается, что «строительства УВСР систематически нарушают договорные обязательства и не создали нормальных условий для размещения и трудоиспользования лагерной рабочей силы... Неоднократные требования НКВД СССР об упорядочении этого дела до сего времени не реализованы. НКВД настаивает на выполнении всех договорных обязательств и создании в течение месяца нормальных условий для работы колоний НКВД. Отсутствие этих условий после указанного срока вынудит НКВД СССР отозвать рабочую силу со строек УВСР» [1, с. 89].

Поскольку наркоматы и их подрядные организации не спешили создавать приемлемые жилищные условия для заключенных, то лагерным начальством направлялись докладные в партийные органы. В докладной записке от 9 сентября 1942 г. на имя секретаря Молотовского (Пермского) ОК ВКП(б) Гусарова говорится: «Колония № 5 обслуживает Мотовилихинский завод. Подготовка к зиме находится под угрозой срыва. Заключенные живут в плохих развалившихся бараках, которые переполнены. Столбы под бараками совершенно сгнили и угрожают обвалом бараков. Дальнейшее оставление заключенных в таких бараках опасно... Начальник колонии неоднократно обращался к руководству завода, но меры никакие не принимаются, оттягивая до глубокой осени, когда будут холода и ремонт производить невозможно.

Колония № 6. Поселок Левшино. Обслуживает пристань Левшино Управления Камского речного пароходства. Хозяйственные организации пристани Левшино не только не выполняют свои необходимые условия по договору, а игнорируют неоднократные указания Левшинского РК ВКП(б) и ОК ВКП(б), обязывающие выполнять договор». Докладная заканчивается просьбой «Вме- 
шаться в это дело и заставить хоз. организации выполнять заключенные договора» [3, д. 6, л. 7-8].

17 октября 1942 г. Наркомат внутренних дел в письме на имя Гусарова сообщает, что задерживает завоз 2500 человек рабочей силы на строительство Азотно-тукового комбината в Губахе из-за неготовности к зиме помещений и лагеря в целом [4, с.144].

В переписке НКВД с другими наркоматами очень часть говорится об угрозе или отказе завозить заключенных из-за отсутствия жилых помещений для их размещения. В связи с неблагополучной обстановкой в размещении заключенных была утверждена «Инструкция о порядке обследования ИТЛ НКВД» специальными комиссиями.

Так, при обследовании лагерного отделения № 3 на станции Баская Молотовской области врач Леонова писала: «Спустя три месяца после организации лагеря, т.е. ко дню его обследования, в лагере отмечается чрезмерная перенаселенность. На одного человека приходится 0,98 кв. м жилой площади, что не отвечает никаким, даже минимальным требованиям; заключенные спят на голых 2-ярусных нарах, без матрацев и соломенных матов, не раздеваясь в течение трех месяцев. При почти беспрерывных дождях в июне и июле месяце одежда и обувь высыхала на людях, т.е. сушилки ни в одном бараке нет» [3, д. 6, л. 11-14].

При проверках с участием членов ГКО и представителей партийных органов похожую картину выявляли и в других местах. В начальный период войны средняя площадь на одного заключенного составляла $1,4 \mathrm{~m}^{2}$, снижаясь по ряду подразделений до 0,5-0,7 м на человека. 80 \% заключенных размещались на сплошных двух и трехъярусных нарах.

Невыполнение планов лагерного строительства было связано с недостатком людских, материальных и транспортных ресурсов, которые, прежде всего, направлялись на фронт.

Тем не менее принимались меры по дополнительному строительству жилых бараков и коммунально-бытовых объектов, капитальному ремонту и утеплению жилого фонда, переоборудованию сплошных нар на двухъярусные вагонного типа, обеспечение жилых бараков необходимым инвентарем.

Принимаемые органами власти меры давали положительные результаты, но общая картина оставалась достаточно противоре- 
чивой на протяжении всей войны. Фактическая обеспеченность жилплощадью на март 1944 г. представляется такой: количество квадратных метров на одного человека в 10 ИТЛ, УИТЛК и ОИТК от 1,2 м $^{2}$ и менее; в 8 - от 1,3 до 1,5 ; в 13 - от 1,5 до 1,7 ; в 29 - от 1,7 до 2 ; в 47 - составляла 2 м $^{2}$ и более.

29 мая 1944 г. был издан Приказ НКВД СССР № 00640, который обязывал к 1 октября 1944 г. довести норму жилой площади во всех лагерных отделениях и колониях до 2 м $^{2}$ на человека. Однако 11 ИТЛ и 12 УИТЛК приказ выполнить не удалось. Обозначились лагеря с самой низкой обеспеченностью жилплощадью Тырны-Аузский $\left(1,1\right.$ м $\left.^{2}\right)$, Воркутинский $\left(1,3 \mathrm{~m}^{2}\right)$, Интинский $\left(1,4 \mathrm{~m}^{2}\right)$ и Норильский $\left(1,5 \mathrm{~m}^{2}\right)$.

Тем не менее уже в 1944 г. жилплощадь удалось довести в среднем до $1,8 \mathrm{~m}^{2}$ на одного заключенного, а для рекордистов и отличников стали отводить целые бараки из расчета $3 \mathrm{~m}^{2}$ на человека, которые были оборудованы койками и комплектом постельных принадлежностей.

Ситуация вновь обострилась в апреле 1945 г., когда в лагеря увеличился приток лиц, связанных с военными преступлениями, и власти вынуждены были в нарушение приказов 1943 и 1944 гг. размещать прибывающих на площади 1,5 м² на человека. Такая обстановка сложилась в одиннадцати УИТЛК и ОИТК [2, д. 329, л. 27].

Тяжелая картина с жилищным вопросом в годы войны была не только в лагерях и колониях, но и местах боевых действий, в попадавших под бомбежку городах и селах, да и в глубоком тылу в связи с эвакуацией из западных областей. Например, на 1 января 1945 г. из 694 строений, находившихся до оккупации в г. Истре, 688 были разрушены полностью. В Великих Луках из 3007 строений 2707 были разрушены полностью, а 303 частично [5, с. 24]. «В Нижнем Тагиле более 7,5 тысячами рабочих жили в бараках с двух - и трехъярусными нарами, в поселке Ново-Тагильского металлургического завода в среднем на одного жителя приходилось всего лишь 1,7 м $^{2}$ жилой площади» [1, с. 90]

Та же картина наблюдалась и в других регионах. Например, в Татарстане 15 сотрудников редакции газеты «Пионерская правда» проживали в комнате площадью $35 \mathrm{~m}^{2}$. В квартире из $14 \mathrm{~m}^{2}$ проживали две семьи по четыре человека, при этом шесть человек из проживающих работали на заводе. В заводских общежи- 
тиях, как правило, на одного человека приходилось от 2 до 4 м² [6, с. 160-161].

В годы войны в качестве жилья учитывались и использовались сараи, амбары, землянки, чердаки, палатки, кузова вагонов, баржи, залы клубов и кино, красные уголки и прочее. Всё это, как и принудительное уплотнение, ветхость жилья и нехватка топлива показывает, что жилищный вопрос, как в местах заключения, так и вне их, был одним из острейших. При всем том он решался и не помешал обеспечению главной задачи победы над фашистским захватчиком.

\section{Список литературы и источников}

1. Тряхов В.Н. ГУЛАГ и война: жестокая правда документов. - Пермь: Пушка, 2004. - С. 399.

2. Государственный архив Российской Федерации (ГАРФ). Ф. 9414. Оп. 1. Д. 34, 35, 45, 77, 328, 329.

3. Пермский государственный архив социально - политической истории. Ф. 2464. Оп. 1. Д. 1, 6.

4. Пермский край в Великой Отечественной войне: энциклопедия. - Пермь: Пушка, 2020.

5. Хлынина Т.П. Жилищный вопрос и практики его разрешения в годы Великой Отечественной войны // Научный диалог. 2014. - № 5 (29): История. Социология. - С. 24.

6. Кабирова А.Ш. Из истории военной повседневности: решение жилищной проблемы в Татарстане в 1941 - 1945 гг. // Ученые записки Казанского госуниверситета. - 2010. - Т. 152. - Кн. 3. Ч. 2. - С. 160-161. 